\title{
JAN EVANGELISTA PURKINJE Libochovice, 1787 - Praga, 1869
}

\author{
NOGUERA-PALAU JJ ${ }^{1}$
}

Si en alguna ocasión viajan ustedes a Praga, o si ya han estado allí, habrán visto o podrán ver por lo menos en dos ocasiones a nuestro personaje motivo de esta nota: en la plaza de Carlos IV, al sur de la Ciudad Vieja, donde en 1961 se dispuso su estatua, y en el calendario de Josef Manes situado debajo del reloj astronómico de la torre del ayuntamiento, Torre del Ayuntamiento de la Ciudad Vieja, edificio construido en 1338 en el que se muestran las copias, óleos sobre una placa de cobre de 2,7 metros de diámetro, de los originales de 1866 conservados en el Museo Municipal.

Jan Evangelista Purkinje, fisiólogo y uno de los padres de la histología moderna, nació el 17 de diciembre de 1787 en Libochovice, localidad de Bohemia, entonces parte del imperio austríaco y ahora, como Bohemia Septentrional, parte de la República Checa. En 1807 comenzó sus estudios de filosofía en la universidad de Praga con la intención de ser sacerdote; allí aprendió latín, alemán, francés e italiano. Después estudió medicina en la praguense Universidad Carolina, la más antigua de las centroeuropeas fundada por el emperador Carlos IV en 1348, en la que se graduó en 1819 con la defensa de su tesis Beitrage zur Kenntniss des Sehens in subjectiver Hinsicht (Contribución al conocimiento de los aspectos subjetivos de la visión); fruto del estudio de diversos aspectos de la función visual, este trabajo despertó el interés de Goethe, favoreció su estrecha amistad con Purkinje y llevó a ambos a colaborar en los fenómenos entópticos de la visión.

Fue adjunto de anatomía y patología hasta que en 1823 el rey Federico III de Prusia lo nombró profesor de fisiología y patología en la universidad de Breslau, ahora Wroclaw en Polonia. En su Commentatio de examine physiologico organi visus et systematis cutanei (Breslau, 1823), no sólo describió las imágenes catóptricas del ojo —las tres imágenes de Purkinje-Sanson- sino además, en un par de breves párrafos, un aparato parecido a un oftalmoscopio con el que podría observarse el interior del ojo, ¡unos 27 años antes que von Helmholtz presentara el suyo!; a pesar de ser anterior el oftalmoscopio de Purkinje, éste nunca llegó a imponerse y apenas fue conocido entre los propios médicos.

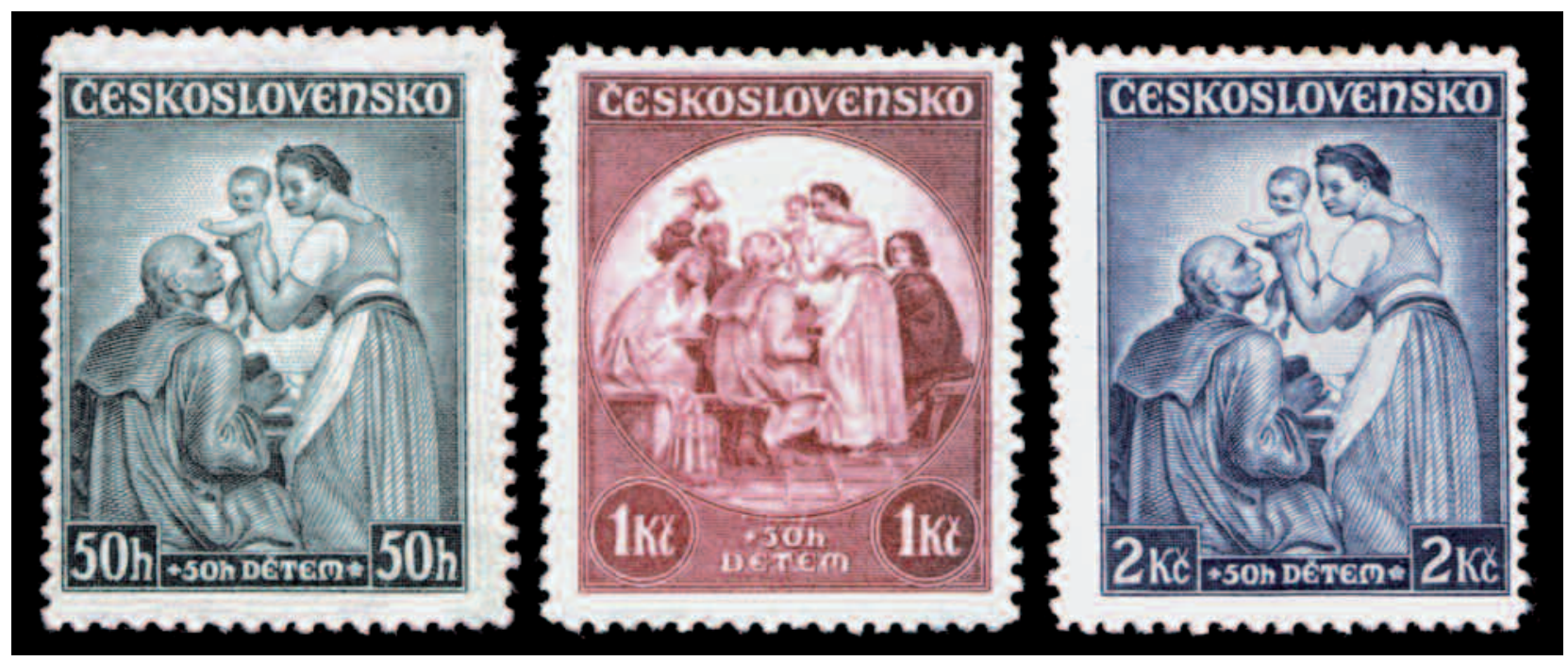

Yvert (1036), 303/5. De un cuadro de Josef Manes.

\footnotetext{
1 Oftalmólogo. Pamplona.

E-mail: jnoguera72b@terra.es
} 


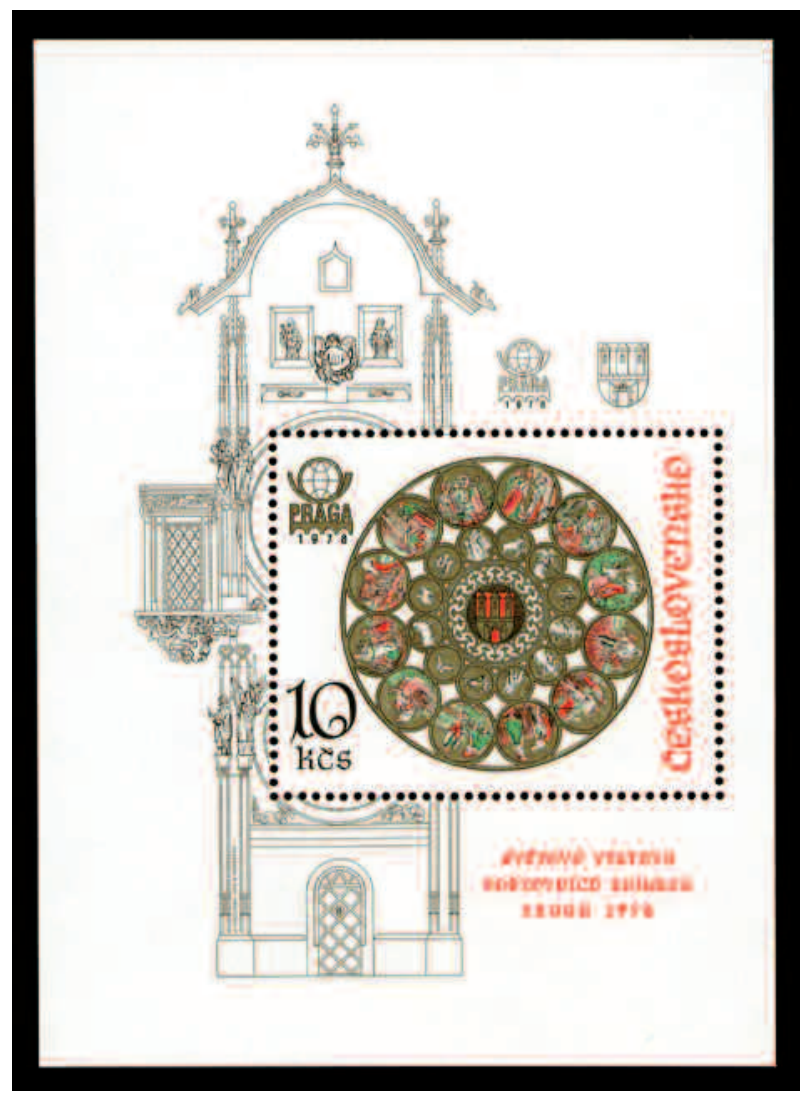

Yvert (1978), HB 43 de 2284/88 + HB $43+H B 43 a$. Calendario de la Torre del Ayuntamiento.

Durante los años que trabajó en Breslau montó un laboratorio de fisiología en el que se dedicó al estudio de la visión, trabajó sobre el nistagmus rotatorio, la visión de los colores y la clasificación de sus alteraciones, los cambios en la percepción de los colores según la adaptación a la oscuridad, las postimágenes, las glándulas sudoríparas, el vértigo, las huellas dactilares, la fisiología del lenguaje, la estructura celular... En 1837 comunicó la existencia de las células cerebelosas que ahora llevan su nombre, y dos años más tarde las fibras de conducción en el corazón. En 1850, tras 27 años en Prusia, regresó a la universidad de Praga como profesor de fisiología donde, como antes en Breslau, también construyó su propio instituto de investigación.

Purkinje mantuvo una estrecha relación con la vida cultural checa y con numerosos artistas. El pintor Josef Manes (1820-1871), buen amigo de la familia Purkinje, utilizó el rostro de Jan Evangelista en alguno de sus cuadros; entre ellos, uno en el que una madre levanta a su hijo en brazos ante Purkinje por el gran parecido de éste con el abuelo de

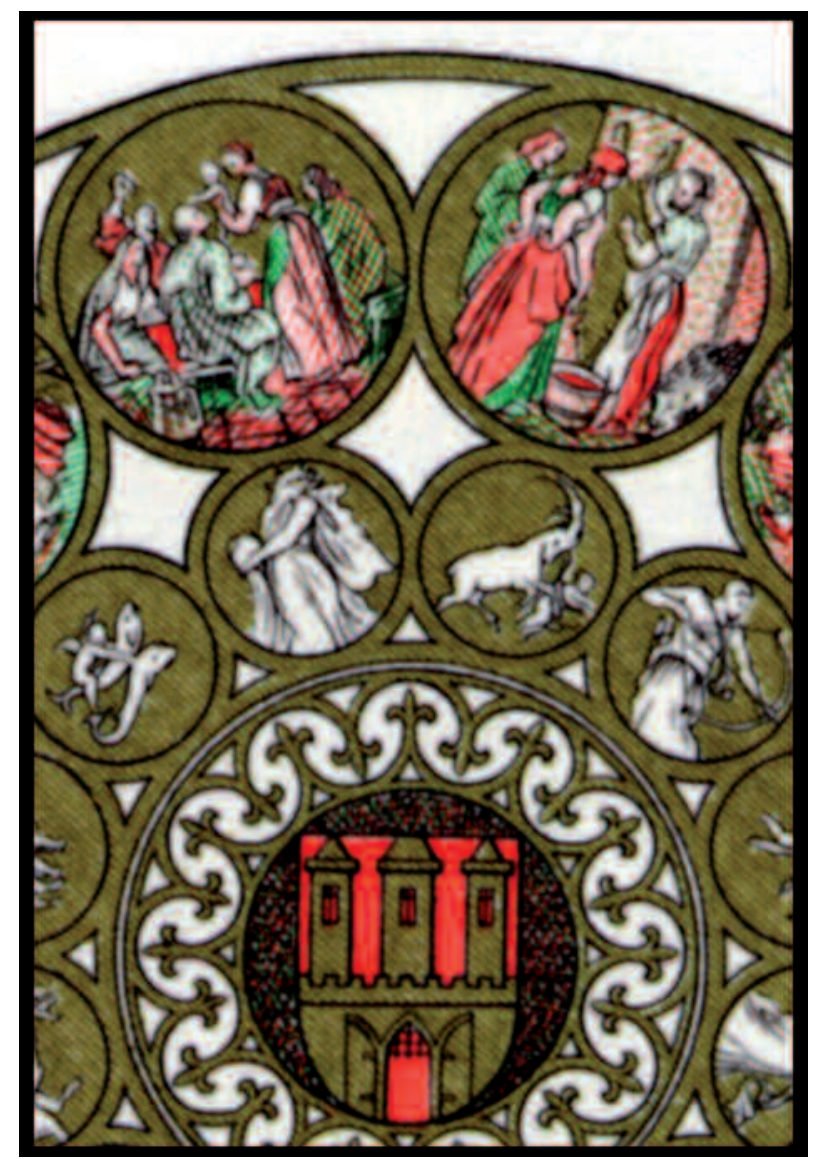

HB 43 - Detalle.

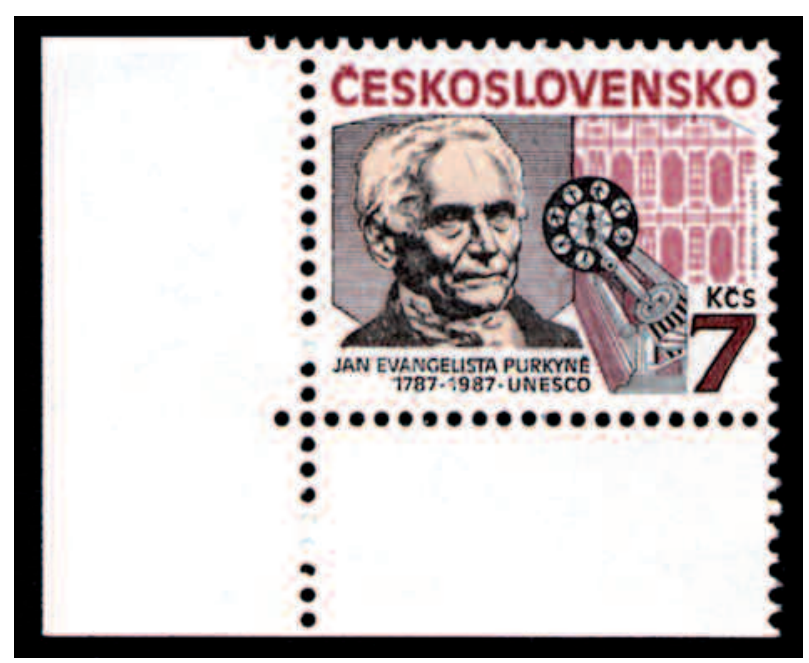

Yvert (1987), 2738 - Purkinje con su modelo de zoótropo.

la criatura. Esta imagen está en el calendario de la Torre del Ayuntamiento de la Ciudad Vieja.

A la edad de 82 años, Jan Evangelista Purkinje falleció en Praga el 28 de julio de 1869. 